\title{
THE 2012 RESULTS OF THE INTERNATIONAL TRADE IN GOODS AND SERVICES IN AND PROSPECTS OF ITS DEVELOPMENT
}

\author{
O.Biryukova, A.Pakhomov
}

In mid-April 2013, the Secretariat of the World Trade Organization (WTO) published an annual analytical review on the basis of the results of development of the international trade in 2012 and the prospects of its development in 2013. The above document includes as well the initial statistical data on the global trade in goods and services by the country in $2012^{1}$.

According to the data of the WTO, in 2012 growth in the global trade in goods amounted in real terms to the mere $2 \%$, which was the worst index since 1981 . In addition to the above, that result turned out to be 0.5 lower than the WTO's experts expected in September 2012.

According to the WTO Secretariat, a sudden slowdown of trade in 2012 was a factor behind weak economic growth in developed countries and resulted in a greater scepsis about the future of the euro area. With global GDP growth of $2.1 \%$ in 2012 , growth in global trade in real terms amounted to $2.1 \%$ and $1.9 \%$ as regards export and import, respectively (as compared to $5.2 \%$ and $5.1 \%$, respectively in 2011$)^{2}$.

"Developments in 2012 should serve as a reminder of structural economic imbalances which were identified, but not eliminated during the economic crisis. Weakness of the global economy will support protectionist sentiments in the world and, as a result, the threat of protectionism to the global trade at present is higher than ever since the crisis began ...", - said Pascal Lamy, the WTO General Director at presentation of the latest analytical review ${ }^{3}$. According to him, the efforts of developed countries to achieve a balance between a renewal of growth and strengthening of the fiscal policy lead to ambiguous results.

According to forecasts of the WTO analysts, in 2013 the world trade volumes will increase only by $3.3 \%$ (though earlier their forecast amounted to $4.5 \%$ ), while in 2014 , by around 5.0\%. For comparison: in the past twenty years (1992-2012) average annual growth in global trade amounted to 5.3\%. Recession in Europe will continue to have a negative effect on the global import as the EU is a large sales market for countries of Asia and America and accounts for $32 \%$ of the global trade. The crisis will affect export from China as well, but consumption in the world's second largest economy keeps growing at a high rate.

For the sake of comparison, it is important to mention the IMF estimate of international trade growth at $2.5 \%$ in 2012 ; it was published virtually simultaneously with that of the WTO Secretariat. According to the IMF, growth in global trade in 2013 and 2014 is expected to amount to $3.6 \%$ and $5.3 \%$, respectively. Such a difference between the IMF forecast and the WTO data is probably justified by a more optimistic view of IMF experts on the prospects of development of the global economy. So, according to the IMF forecast in 2013 the global growth rates will amount to $3.4 \%$ against $3.3 \%$ in 2012 . Generally, despite the fact that all the previous problems still prevailed the IMF assessed risks to the global economy as reduced ones in the short-term prospect ${ }^{4}$.

Experts of the United Nations Organization hold fairly optimistic views, too. According to their report - The World Economic Situation and Prospects in 2013 - in the current year global trade growth will increase somewhat and get closer to the long-term trends of the 5\% growth

\footnotetext{
1 World Trade 2012, Prospects for 2013, Trade to remain subdued in 2013 after sluggish growth in 2012 as European economies continue to struggle, WTO Secretariat Geneva, PRESS/688, 10 April 2013, 27 p.

2 Despite extremely slow rates of growth in the volume of trade, the ratio of the global export of goods and services to global GDP in current prices amounted to $32 \%$ (28\% during the crisis), which value was close to the maximum value of $33 \%$ in 2008 .

3 http://www.wto.org/english/news_e/pres13_e/pr688_e.htm

4 IMF World Economic Outlook (WEO), Hopes, Realities, and Risks, Wash., April 2013, 204 p.; http://www.imf.org/ external/pubs/ft/weo/2013/01/pdf/text.pdf
} 
by $2014^{1}$. Developing countries turned out to be more resilient to a new recession and their importance in the world trade keeps growing together with progressive integration into global technological chains.

In 2012, in nominal terms the volumes of the international trade in goods increased by the mere $0.2 \%$ to $\$ 18.2$ trillion. It took place to a great extent due to a sudden drop in global prices on a number of traditional export commodities, such as coffee $(-22 \%)$, cotton $(-42 \%)$, coal $(-21 \%)$ and iron ore $(-23 \%)$. However, prices on energy carriers did not virtually change $(+1 \%)^{2}$.

Generally, in the past year the minimum changes took place in the list of the world' leading exporters and importers of commodities (Table 1). According to the WTO data, on the basis of the 2012 results China (with the volume of $\$ 2,049 \mathrm{bn}$ and share of $11.2 \%$ in the global export) was again at the top of rating of the largest suppliers leaving behind the US (\$1,547bn and 8.4\%) and Germany $(\$ 1,407 \mathrm{bn}$ and $7.7 \%)$. The US remains at the top list of the largest importers (with the volume of $\$ 2,335 \mathrm{bn}$ and share of $12.6 \%$ in the global import) to be followed by China ( $\$ 1,818 \mathrm{bn}$ and $9.8 \%)$ and Germany $(\$ 1,167 \mathrm{bn}$ and $6.8 \%)$.

Table 1

THE LEADING EXPORTERS AND IMPORTERS IN THE GLOBAL TRADE IN COMMODITIES IN 2012

\begin{tabular}{|c|c|c|c|c|c|c|c|c|c|}
\hline$\frac{\ddot{\Xi}}{\tilde{\sigma}}$ & Exporter-country & $\begin{array}{c}\text { Volume, } \\
\text { billion } \\
\text { USD }\end{array}$ & Share, \% & $\begin{array}{c}\text { Change } \\
\text { as \% to } \\
2011\end{array}$ & 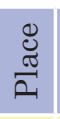 & Importer-country & $\begin{array}{c}\text { Volume, } \\
\text { billion } \\
\text { USD }\end{array}$ & $\begin{array}{c}\text { Share, } \\
\%\end{array}$ & $\begin{array}{c}\text { Change } \\
\text { as \% to } \\
2011\end{array}$ \\
\hline 1 & China & 2049 & 11,2 & 8 & 1 & USA & 2335 & 12,6 & 3 \\
\hline 2 & USA & 1547 & 8,4 & 5 & 2 & China & 1818 & 9,8 & 4 \\
\hline 3 & Germany & 1407 & 7,7 & -5 & 3 & Germany & 1167 & 6,3 & -7 \\
\hline 4 & Japan & 799 & 4,4 & -3 & 4 & Japan & 886 & 4,8 & 4 \\
\hline 5 & The Netherlands & 656 & 3,6 & -2 & 5 & The UK & 680 & 3,7 & 1 \\
\hline 6 & France & 569 & 3.1 & -5 & 6 & France & 674 & 3.6 & -6 \\
\hline 7 & Republic of Korea & 548 & 3 & -1 & 7 & The Netherlands & 591 & 3.2 & -1 \\
\hline \multirow[t]{2}{*}{8} & Russian Federation & 529 & 2.9 & 1 & 8 & Hong Kong, China & 554 & 3 & 8 \\
\hline & & & & & & $\begin{array}{l}\text { - import for domestic } \\
\text { consumption }\end{array}$ & 140 & 0.8 & 6 \\
\hline 9 & Italy & 493 & 2.7 & -4 & 9 & Republic of Korea & 520 & 2.8 & -1 \\
\hline \multirow{3}{*}{10} & Hong Kong, China & 22 & 2.7 & 8 & 10 & India & 489 & 2.6 & 5 \\
\hline & $\begin{array}{l}\text { - export of goods of } \\
\text { domestic production }\end{array}$ & 471 & 0.1 & 33 & & & & & \\
\hline & - re-export & 468 & 2.6 & 7 & & & & & \\
\hline 11 & The UK & 455 & 2.6 & -7 & 11 & Italia & 486 & 2.6 & -13 \\
\hline 12 & Canada & 455 & 2.5 & 1 & 12 & Canada $^{3}$ & 475 & 2.6 & 2 \\
\hline 13 & Belgium & 446 & 2.4 & -6 & 13 & Belgium & 435 & 2.3 & -7 \\
\hline \multirow[t]{3}{*}{14} & Singapore & 408 & 2.2 & 0 & 14 & Mexico & 380 & 2 & 5 \\
\hline & $\begin{array}{l}\text { - export of goods of } \\
\text { domestic production }\end{array}$ & 228 & 1.2 & 2 & & & & & \\
\hline & - реэкспорт & 180 & 1 & -3 & & & & & \\
\hline \multirow[t]{2}{*}{15} & Saudi Arabia ${ }^{5}$ & 386 & 2.1 & 6 & 15 & Singapore & 380 & 2 & 4 \\
\hline & & & & & & $\begin{array}{l}\text { - import for domestic } \\
\text { consumption }^{4}\end{array}$ & 199 & 1.1 & 11 \\
\hline 16 & Mexico & 371 & 2 & 6 & 16 & Russian Federation $^{3}$ & 335 & 1,8 & 4 \\
\hline 17 & Taiwan, China & 301 & 1.6 & -2 & 17 & Spain & 332 & 1,8 & -12 \\
\hline 18 & $\mathrm{UAE}^{5}$ & 300 & 1.6 & 5 & 18 & Taiwan, China & 270 & 1.5 & -4 \\
\hline 19 & India & 293 & 1.6 & -3 & 19 & Australia & 261 & 1.4 & 7 \\
\hline 20 & Spain & 292 & 1.6 & -5 & 20 & Thailand & 248 & 1.3 & 8 \\
\hline 21 & Austria & 257 & 1.4 & -5 & 21 & Turkey & 237 & 1.3 & -2 \\
\hline
\end{tabular}

1 World Economic Situation and Prospects 2013, United Nations, New York, 2013. The report is a joint product of the United Nations Department of Economic and Social Affairs (UN/DESA), the United Nations Conference on Trade and Development (UNCTAD) and the five United Nations regional commissions. 207 p.

2 World Trade 2012, Prospects for 2013, Trade to remain subdued in 2013 after sluggish growth in 2012 as European economies continue to struggle, WTO Secretariat Geneva, PRESS/688, 10 April 2013, p.10.

3 Import at FOB price.

4 Import for Singapore's domestic consumption is determined as the aggregate import less re-export.

5 Estimate of the WTO Secretariat. 
Table 1, cont'd

\begin{tabular}{|c|c|c|c|c|c|c|c|c|c|}
\hline 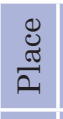 & Exporter-country & $\begin{array}{c}\text { Volume, } \\
\text { billion } \\
\text { USD }\end{array}$ & Share, \% & $\begin{array}{c}\text { Change } \\
\text { as } \% \text { to } \\
2011\end{array}$ & $\frac{\ddot{\Xi}}{\pi}$ & Importer-country & $\begin{array}{c}\text { Volume, } \\
\text { billion } \\
\text { USD }\end{array}$ & $\begin{array}{c}\text { Share, } \\
\%\end{array}$ & $\begin{array}{c}\text { Change } \\
\text { as \% to } \\
2011\end{array}$ \\
\hline 22 & Brazil & 243 & 1.3 & -5 & 22 & Brazil & 233 & 1.3 & -2 \\
\hline 23 & Thailand & 230 & 1.3 & 3 & 23 & $\mathrm{UAE}^{3}$ & 220 & 1.2 & 7 \\
\hline 24 & Malaysia & 227 & 1.2 & 0 & 24 & Switzerland & 198 & 1.1 & -5 \\
\hline 25 & Switzerland & 226 & 1.2 & -4 & 25 & Malaysia & 197 & 1.1 & 5 \\
\hline 26 & Indonesia & 188 & 1 & -6 & 26 & Poland & 196 & 1.1 & -7 \\
\hline 27 & Poland & 183 & 1 & -3 & 27 & Indonesia & 190 & 1 & 8 \\
\hline 28 & Sweden & 172 & 0.9 & -8 & 28 & Austria & 178 & 1 & -7 \\
\hline 29 & Austria & 166 & 0.9 & -6 & 29 & Sweden & 162 & 0.9 & -8 \\
\hline 30 & Norway & 160 & 0.9 & 0 & 30 & Saudi Arabia $^{3}$ & 144 & 0.8 & 9 \\
\hline & otally by 30 countries ${ }^{4}$ & 14870 & 81.2 & - & \multicolumn{2}{|c|}{ Totally by 30 countries ${ }^{4}$} & 152270 & 82.3 & - \\
\hline & The world as a whole ${ }^{4}$ & 18325 & 100 & 0 & \multicolumn{2}{|r|}{ The world as a whole ${ }^{4}$} & 18565 & 100 & 0 \\
\hline
\end{tabular}

${ }^{1}$ Import at FOB price.

${ }^{2}$ Import for Singapore's domestic consumption is determined as the aggregate import less re-export.

${ }^{3}$ Estimate of the WTO Secretariat.

${ }^{4}$ Including considerable re-export or import for re-export purposes.

Source: WTO Secretariat, Press release, PRESS/688, Geneva, April 10, 2013, p.21 (Appendix Table 3 "Merchandise Trade: Leading Exporters and Importers, 2011”).

A somewhat improvement of the position of the Russian Federation in the list of the largest exporter-countries (the $8^{\text {th }}$ place as compared to the $9^{\text {th }}$ in 2011 ) was justified mostly by a favorable prices on energy carriers and a number of primary products, as well as declining dynamics of import in some developed countries. It is to be noted that the share of the country in the global export remained unchanged (2.9\%). As regards import, Russia moved one place upward to the $16^{\text {th }}$ place, while its unit weight remained the same $(1.8 \%)$.

In 2012 , the global export of commercial services rose by $2 \%$ and amounted to $\$ 4.3 \mathrm{bn}$. In accordance with global trends, supplies of transport services grew by $2 \%$, export of the group of other types of commercial services rose by the mere $1 \%$, while the largest increase of $4 \%$ was registered as regards the "travelling" item (Table 2).

Table 2

DYNAMICS OF THE GLOBAL EXPORT OF GOODS AND SERVICES IN THE 2005-2012 PERIOD

\begin{tabular}{|c|c|c|c|c|c|}
\hline & Fxnort 2012 & & Grow & tes, $\%$ & \\
\hline & billion USD & 2010 & 2011 & 2012 & $\begin{array}{c}2005- \\
2012\end{array}$ \\
\hline Goods & 18323 & 22 & 20 & 0 & 8 \\
\hline Services & 4345 & 10 & 11 & 2 & 8 \\
\hline Transport & 885 & 16 & 9 & 2 & 7 \\
\hline Travelling & 1105 & 9 & 12 & 4 & 7 \\
\hline Other commercial services, including: & 2350 & 8 & 12 & 1 & 10 \\
\hline Communications & 100 & 3 & 10 & -3 & 8 \\
\hline Building & 110 & -4 & 8 & 3 & 10 \\
\hline Insurance & 100 & 1 & 0 & 2 & 11 \\
\hline Finance & 300 & 7 & 12 & -4 & 8 \\
\hline Computer and information services & 265 & 12 & 14 & 6 & 14 \\
\hline Royalties and license fees & 285 & 8 & 14 & -2 & 9 \\
\hline Other business services & 1145 & 9 & 13 & 2 & 9 \\
\hline Services in the sphere of culture and recreation & 35 & 14 & 13 & 3 & 7 \\
\hline
\end{tabular}

Source: World Trade 2012, Prospects for 2013, Trade to remain subdued in 2013 after sluggish growth in 2012 as European economies continue to struggle, WTO Secretariat Geneva, PRESS/688, 10 April 2013, p. 11.

Among other types of commercial services, the export of computer and information services was developing more dynamically (growth of 6\%). Development of the segment of services in global in- 
formation and communications technologies (ICT) forms a brain center of the information economy as it creates the intellectual base of goods and services, production technologies and business processes. As regards the volume of export of "intelligent" products, the leaders are still the US and the EU where the largest part of the global intellectual potential in that area is concentrated ${ }^{1}$.

Along with computer and information technologies, the export of building and insurance services increased as well ( $3 \%$ and $2 \%$, respectively); other types of business services covering legal advice, accounting services, consulting, advertizing, marketing and engineering services which segment is important to commercialization of innovation activities rose by $2 \%$.

The leading positions on the global market of engineering services are occupied invariably by companies from the US, France, the UK, Japan, Germany, Italy, Canada and Sweden. The geographic pattern of the market of engineering services is characterized by prevalence of export to developing countries most of which are oil-producing states of the Middle East and Asia ${ }^{2}$. In the past few years, engineering companies from developed countries face competition on the part of local companies and economic operators from Brazil, Mexico, India, China and other.

At the same time, in 2012 the export of financial services suffered a great deal (-4\%). In 2012 in general, supply of financial services from developed countries decreased by $6 \%$ with a parallel increase of $3 \%$ in export from developing countries and CIS states. In addition to the above, there was a decrease in supplies of communication services, including mail, courier and telecommunication services $(-3 \%)$, as well as royalties and license fees $(-2 \%)$.

On the global level, in 2012 in the sphere of supply of commercial services the leaders remained unchanged (Table 3). The top positions were occupied again by the US (the globak export volume of $\$ 614 \mathrm{bn}$ and share of $14.1 \%$ in the global export), the UK (\$278bn and 6.4\%) and Germany ( $\$ 255 \mathrm{bn}$ and 5.9\%). Among consumers of services, the leaders were the US (the global import volume $\$ 406 \mathrm{bn}$ and the unit weight in global import - 9.9\%), Germany (\$285bn and 6.9\%) and China (\$281bn and 6.8\%).

Table 3

LEADING EXPORTERS AND IMPORTERS IN GLOBAL TRADE IN COMMERCIAL SERVICES * IN 2012

\begin{tabular}{|c|c|c|c|c|c|c|c|c|c|}
\hline$\underset{\frac{\pi}{\pi}}{\approx}$ & Exporter-country & $\begin{array}{c}\text { Volume, } \\
\text { billion } \\
\text { USD }\end{array}$ & $\begin{array}{c}\text { Share, } \\
\%\end{array}$ & $\begin{array}{l}\text { Change } \\
\text { as \% to } \\
2011 \text {, }\end{array}$ & $\frac{8}{0}$ & Importer-country & $\begin{array}{l}\text { Volume, } \\
\text { billion USD }\end{array}$ & $\begin{array}{c}\text { Share, } \\
\%\end{array}$ & $\begin{array}{c}\text { Change } \\
\text { as \% to } \\
2011 \text {, }\end{array}$ \\
\hline 1 & The USA & 614 & 14,1 & 4 & 1 & The USA & 406 & 9,9 & 3 \\
\hline 2 & The UK & 278 & 6,4 & -4 & 2 & Germany & 285 & 6,9 & -3 \\
\hline 3 & Germany & 255 & $5,9,1$ & -2 & 3 & China & 281 & 6,8 & 19 \\
\hline 4 & France & 208 & 4,8 & -7 & 4 & The UK & 176 & 4,3 & 1 \\
\hline 5 & China & 190 & 4,4 & 4 & 5 & Japan & 174 & 4,2 & 5 \\
\hline 6 & India & 148 & 3,4 & 8 & 6 & France & 171 & 4,2 & -10 \\
\hline 7 & Japan & 140 & 3,2 & -2 & 7 & India & 125 & 3 & 1 \\
\hline 8 & Spain & 140 & 3,2 & -1 & 8 & Singapore & 117 & 2,8 & 3 \\
\hline 9 & Singapore & 133 & 3,1 & 3 & 9 & The Netherlands & 115 & 2,8 & -5 \\
\hline 10 & The Netherlands & 126 & 2.9 & -7 & 10 & Ireland & 110 & 2.7 & -5 \\
\hline 11 & $\begin{array}{l}\text { Hong Kong, } \\
\text { China }\end{array}$ & 126 & 2.9 & 7 & 11 & Canada & 105 & 2.6 & 1 \\
\hline 12 & Ireland & 115 & 2.6 & 2 & 12 & Republic of Korea & 105 & 2.6 & 7 \\
\hline 13 & Republic of Korea & 109 & 2.5 & 16 & 13 & Italy & 105 & 2.6 & -8 \\
\hline 14 & Italy & 104 & 2.4 & -1 & 14 & $\begin{array}{l}\text { Russian } \\
\text { Federation }\end{array}$ & 102 & 2.5 & 16 \\
\hline 15 & Belgium & 94 & 2.2 & 0 & 15 & Belgium & 90 & 2.2 & -1 \\
\hline 16 & Switzerland & 88 & 2 & -7 & 16 & Spain & 90 & 2.2 & -5 \\
\hline 17 & Canada & 78 & 1.8 & -1 & 17 & Brazil & 78 & 1.9 & 7 \\
\hline 18 & Sweden & 76 & 1.7 & 2 & 18 & Australia & 65 & 1.6 & 10 \\
\hline
\end{tabular}

1 Services in Modern Economy / responsible editors L.S. Demidova and V.G. Kondratiev - Moscow: IMEMO RAN, 2010. p. 238

2 See: D.V. Rybets. Engineering (Engineering and Consulting Services) on the Global Market. Russian Foreign Economic Bulletin, No. 8, 2011. pp. C. 89, 91. 
Table 3, cont'd

\begin{tabular}{|c|c|c|c|c|c|c|c|c|c|}
\hline 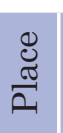 & Exporter-country & $\begin{array}{l}\text { Volume, } \\
\text { billion } \\
\text { USD }\end{array}$ & $\begin{array}{l}\text { Share, } \\
\%\end{array}$ & $\begin{array}{c}\text { Change } \\
\text { as \% to } \\
2011\end{array}$ & $\frac{\mathscr{\Xi}}{\pi}$ & Importer-country & $\begin{array}{l}\text { Volume, } \\
\text { billion USD }\end{array}$ & $\begin{array}{l}\text { Share, } \\
\%\end{array}$ & $\begin{array}{c}\text { Change } \\
\text { as \% to } \\
2011 \text {, }\end{array}$ \\
\hline 19 & Luxemburg & 70 & 1.6 & 0 & 19 & Denmark & 57 & 1.4 & -2 \\
\hline 20 & Denmark & 65 & 1.5 & -2 & 20 & $\begin{array}{l}\text { Hong Kong, } \\
\text { China }\end{array}$ & 57 & 1.4 & 2 \\
\hline 21 & Austria & 61 & 1.4 & 1 & 21 & Sweden & 55 & 1.3 & 0 \\
\hline 22 & $\begin{array}{l}\text { Russian } \\
\text { Federation }\end{array}$ & 58 & 1.3 & 10 & 22 & Thailand & 53 & 1.3 & 1 \\
\hline 23 & Australia & 53 & 1.2 & 4 & 23 & $\mathrm{UAE}^{* *}$ & 50 & 1.2 & $\ldots$ \\
\hline 24 & Norway & 50 & 1.2 & 3 & 24 & Saudi Arabia & 49 & 1.2 & -10 \\
\hline 25 & Thailand & 49 & 1.1 & 18 & 25 & Norway & 49 & 1.2 & 6 \\
\hline 26 & Taiwan, China & 49 & 1.1 & 7 & 26 & Switzerland & 44 & 1.1 & -2 \\
\hline 27 & Macao, China & 45 & 1 & 14 & 27 & Austria & 43 & 1.1 & 3 \\
\hline 28 & Turkey & 42 & 1 & 9 & 28 & Taiwan. China & 42 & 1 & 2 \\
\hline 29 & Brazil & 38 & 0.9 & 5 & 29 & Malaysia & 42 & 1 & 10 \\
\hline 30 & Poland & 38 & 0.9 & 1 & 30 & Luxemburg & 41 & 1 & 0 \\
\hline & $\begin{array}{l}\text { Totally by } 30 \\
\text { countries }\end{array}$ & 3640 & 83.7 & - & & $\begin{array}{l}\text { Totally by } 30 \\
\text { countries }\end{array}$ & 3285 & 80 & \\
\hline The & world as a whole & 4345 & 100 & 2 & The & e world as a whole & 4105 & 100 & 2 \\
\hline
\end{tabular}

* Foreign trade in commercial services means fulfillment by one side of paid jobs (services) which are not directly related to creation of material valuables for the other side. Non-commercial services mainly include the so-called public services which are rendered inside the country and beyond the competitive environment.

** Preliminary estimates. The data on a number of countries and territories is based on the estimates of the WTO Secretariat.

Source: WTO and UNCTAD Secretariats, Press release, PRESS/688, Geneva, April 10, 2013, p.23 (Appendix Table 5 "Leading Exporters and Importers in world trade in commercial services, 2012").

According to the WTO data, in 2012 despite growth of 10\% the Russian Federation retained the $22^{\text {nd }}$ place among exporters of services. The share of the country in global supplies amounted to the mere $1.3 \%$ which figure is evidence of both the low involvement of Russian companies in the international exchange of services and insufficient development of that sector in the system of the country's foreign economic relations. As regards the import of commercial services (import volume $-\$ 102 \mathrm{bn}$ and growth of $13 \%$ ), the country moved one place upward and occupied the $14^{\text {th }}$ place in the world, while its unit weight increased to $2.5 \%$ as compared to $2.3 \%$ in $2011^{1}$.

On the basis of the results of 2012, Russia's positioning in the global trade in goods and services did not virtually change (Table 4).

Table 4

DYNAMICS OF RUSSIA'S POSITIONS IN THE WTO RATING AND ITS SHARE IN THE GLOBAL TRADE IN GOODS AND SERVICES IN THE 2000-2012 PERIOD*

\begin{tabular}{|l|c|c|c|c|c|c|c|c|c|c|}
\hline & 2000 & 2005 & 2006 & 2007 & 2008 & 2009 & 2010 & 2011 & 2012 \\
\hline Export of goods & $17 / 1.7$ & $13 / 2.4$ & $13 / 2.5$ & $12 / 2.5$ & $9 / 2.9$ & $13 / 2.4$ & $12 / 2.6$ & $9 / 2.9$ & $8 / 2.9$ \\
\hline Import of goods & $29 / 0.7$ & $19 / 1.2$ & $18 / 1.3$ & $16 / 1.6$ & $16 / 1.8$ & $17 / 1.5$ & $18 / 1.6$ & $17 / 1.8$ & $16 / 1.8$ \\
\hline Export of services & $31 / 0.7$ & $26 / 1.1$ & $25 / 1.1$ & $25 / 1.2$ & $22 / 1.3$ & $22 / 1.3$ & $23 / 1.2$ & $22 / 1.3$ & $22 / 1.3$ \\
\hline Import of services & $22 / 1.2$ & $17 / 1.6$ & $18 / 1.7$ & $16 / 1.9$ & $16 / 2.2$ & $16 / 1.9$ & $16 / 2.0$ & $15 / 2.3$ & $14 / 2.5$ \\
\hline
\end{tabular}

* The first figure means the place in the rating; the second figure - the share, $\%$.

Source: calculated on the basis of the WTO data in the respective years.

Unlike trade in commodities, the Russian Federation's trade balance of services is invariably negative: in 2012 the deficit of trade in services amounted to its historic maximum of $\$ 46.2 \mathrm{bn}^{2}$. It is

1 WTO Secretariat, Press release, PRESS/658, Geneva, April 12, 2012, p. 20.

2 The data of the Central Bank of the Russian Federation; Electronic access regime: http://www.cbr.ru/ statistics/?prtid=svs 
to be noted that the "traveling" item accounts for nearly $70 \%$ of the entire deficit of trade in services which fact can be explained by well-established orientation of foreign traveling and business trips to far abroad countries ${ }^{1}$. In addition to the above, Russia had traditionally a negative balance as regards items related to provision of building, financial, insurance, telecommunications, technical and computer services, as well as most other types of business services ${ }^{2}$.

The importance of the services sector for Russian economy is growing, however, the share of the export of services in the country's aggregate export remains virtually unchanged, that is, $10-11 \%$ which is much below the worldwide average of $19 \%^{3}$. In years to come, with an adequate state support rendered growth in supply of services may become an important line of both diversification of the Russian export and reduction of the share of its primary product component; at present such support is virtually non-existent.

For realization of the potential, Russian exporters of services have to expand the range of services with making them oriented on new, science-intensive types of services, raise the competitive edge of traditional services, including transport and tourist services and actively enter the promising markets of services, particularly, by means of establishment of subsidiaries and branches (the so-called commercial presence).

At the current stage, the importance of growth in supply of services is justified by the fact that in the short-term prospect annual growth in physical volumes of export of goods will not exceed $2.8 \%$ with a lack of a considerable potential to build up export supplies of oil, oil products and metallurgical products. So, as before the dynamics of the Russian export will be determined by global prices on primary products. According to the forecast of the Ministry of Economic Development, in 2013 a decrease in the monetary volumes of export to $\$ 526 \mathrm{bn}$ is expected (in the worst-case scenario it will amount to $\$ 505 \mathrm{bn})^{4}$.

It is to be noted that worsening of the index of export diversification due to constant growth in the unit weight of energy carriers and primary products is typical of Russia. In the total export of commodities, the share of export as regards the "machines, equipment and the means of transportation" item fell from $8.5 \%$ in 2000 to $4.9 \%$ in 2012 ; it is to be noted that the produce of the military and industrial complex accounted for over a half of the volume ${ }^{5}$.

Such state of things in the foreign trade has a negative effect on development of domestic trade and reflects the level of its competitiveness. To diminish that effect, large-scale restructuring at the macro and micro levels of the country's economic mechanisms, including the system of state regulation of foreign trade is required.

1 In 2012, as regards tourists expenditures abroad Russia was rated the world's fifth (\$43bn) which is by one-third more than in the previous year. The top four places were occupied by China ( $\$ 102 \mathrm{bn})$, Germany and the US ( $\$ 84 \mathrm{bn}$ each). Rossiiskaya Gazeta, April 11, 2013.

2 O.V Biryukova. The Main Guidelines of Ensuring Economic Interests of Russian Exporters in the International Trade in Services // The Russian Foreign Economic Bulletin. 2012. No. 6. P. 89.

3 UNCTAD Handbook of Statistics, United Nations, New York and Geneva, 2012. P. 2, 278.

4 Explanatory note on the scenario conditions for formation of different versions of the forecast of social and economic development in the 2013-2015 period. The Ministry of Economic Development of the Russian Federation. April 2013, pp. 34-35.

5 Russia in Figures. 2012: Short Statistical Bulletin. M.: Rosstat, 2012. P. 544. 